\title{
Improving students' vocabulary through Funny Stories at the second grade of SMA Yadika Bandar Lampung
}

\author{
Violita Cahya Rivai ${ }^{1}$ Cucu Sutarsyah ${ }^{2}$ Flora Nainggolan ${ }^{3}$ \\ Universitas Lampung, Jl. Prof. Dr. Sumantri Brojonegoro, Rajabasa, Bandarlampung ${ }^{1,2,3}$ \\ ${ }^{1}$ Correspondence e-mail: violitacahya1998@gmail.com
}

\begin{abstract}
The objectives of this research were to find out whether teaching by using Funny Stories could give improvement toward students' vocabulary or not and to find out the students responses in learning vocabulary by using funny stories. This research was conducted at the second grade of SMA YADIKA Bandar Lampung in the academic year 2020/2021 using one group pretestposttest design. The sample of this research was XI IPA 1 class which consisted of 30 students. The instrument of this study was vocabulary test in multiple choices. The tests were given to see how far the students improve their vocabulary after the treatment. The data were analyzed by usinf SPPS 16.0. The result of the research showed that $t$-value (10.266) was higher than $t$-table (2.042) and the value of a significant level was $0.00<0.005$. it means that there is an improvement of students' scores in vocabulary test after the implementation of Funny Stories. The mean score of pre-test was (77.08) and the mean score of post-test was (86.17) it means the students improved about 9.08. In addition, it was found out that 29 students (96.7\%) had positive responses and one student (3.3\%) had a negative response after the use of funny stories. Thus, the result of sudents questionnaire had shown that most of the students had positive responses after the use of funny stories of teaching vocabulary test.
\end{abstract}

Keyword: Funny Stories, Vocabulary, Response.

\section{INTRODUCTION}

Vocabulary as one of language components is a very important thing besides other language components. Without vocabulary, people will not be able to say anything. Starting from word, people can say what they want to say or write. Hatch and Brown (1995) state that vocabulary refers to a list or set of words for a particular language or a list or set of words that individual speaker of a language might use. Thornbury (2002) states that without grammar very little can be conveyed, without vocabulary nothing can be conveyed. It shows that vocabulary is very important, even though people have good ability in structures, but they do not have good enough vocabulary to express their idea, the structures are useless.

Richard and Renandya (2002) say that vocabulary is a core component of language proficiency and provides much of the basis for how well learners speak, listen, read, and write. It means that to improve their language skills, learners must master vocabulary. However, there are some common problems faced by students in vocabulary. The students' often find difficulties in understanding meaning of unknown words from the context because of their low vocabulary mastery (Arafa, 2018)

Nowadays the students need a story, such as short story, funny story, fairy tales, and other kinds. In this case, the researcher will use a funny story to improve students' vocabulary. 
Through funny stories, students can improve their vocabulary and enhance their overall language proficiency. Hernawati (2015) stated that Funny Stories is good for learning and teaching English vocabulary because it will train the students' brain, interest, and challenge. And then, this technique can make the students easy to understand the meaning of the words.

In addition, Astuti (2005) in her thesis said that it is very good for the teachers telling funny stories when they teach in the class. It can reduce stress and avoid the students from getting bored, relaxes a stuffy environment because they are all laughing together. Making the learning process more enjoyable can assist in making it more effective and also experiences and motivating for them in making decision. Besides, the students will be able to improve their language skill. They will learn new words and practice them in reading stories.

Based on previous research it could be said that those studies have proved that the use of funny stories is good to be implemented for improving students' vocabulary. Because the researcher wants to make the teaching learning process will be more fun and enjoyable.

\section{METHODS}

This research used quantitative method which used one-group pre-test post-test design (Setiyadi, 2006). The researcher investigated whether there was a significant improvement in students' vocabulary by using Funny Stories and found out students' responses after the implementation of Funny Stories. The instruments of this research were vocabulary test and response questionnaire. The researcher took one class through random sampling as sample of this research. The population of this research were the second year students of SMA YADIKA Bandar Lampung and the sample was XI science 1 consisted of 29 students. The researcher conducted the pre-test to measure students' ability in comprehending the text before the treatment. After giving the pre-test, the treatment were conducted in two times. To know the result, the researcher gave post-test to measure students' ability in comprehending the text after the treatment. Then, the researcher compared the result between pre-test and post-test and analyzed it using Paired Sample T-Test.

\section{RESULTS AND DISCUSSIONS}

\section{Results}

After conducting the research, the researcher gathers the results of the pre-test and post-test after the implementation of Funny Stories.

Table 1. The Improvement of Students' Vocabulary Score in Pre-Test and Post-Test

\begin{tabular}{|ccc|}
\hline Mean Score of Pre-test & Mean Score of Post-test & Gain \\
\hline 77.08 & 86.17 & 9.08 \\
\hline
\end{tabular}


Table 1 shows that the mean score of the pre-test is 77.08 and the mean score of the post-test is 86.17. It is clear that the students' vocabulary increased after the implementation of Funny Stories strategy with the gain is 9.08 .

Table 2. T-Test Result of Hypothesis Analysis

Paired Samples Test

\begin{tabular}{|c|c|c|c|c|c|c|c|c|}
\hline & \multicolumn{5}{|c|}{ Paired Differences } & \multirow[t]{3}{*}{$\mathrm{T}$} & \multirow[t]{3}{*}{ Df } & \multirow{3}{*}{$\begin{array}{l}\text { Sig. (2- } \\
\text { tailed) }\end{array}$} \\
\hline & \multirow[t]{2}{*}{ Mean } & \multirow[t]{2}{*}{$\begin{array}{c}\text { Std. } \\
\text { Deviation }\end{array}$} & \multirow[t]{2}{*}{$\begin{array}{c}\text { Std. Error } \\
\text { Mean }\end{array}$} & \multicolumn{2}{|c|}{$\begin{array}{c}\text { 95\% Confidence } \\
\text { Interval of the } \\
\text { Difference }\end{array}$} & & & \\
\hline & & & & Lower & Upper & & & \\
\hline $\begin{array}{ll}\text { Pair } & \text { post-test - } \\
1 & \text { pre-test }\end{array}$ & 9.08333 & 4.84605 & .88476 & 7.27379 & 10.89288 & 10.266 & 29 & .000 \\
\hline
\end{tabular}

Table 2 provides evidence that the t-value was 10.266 and the two tail significance showed that significant $<0.05$ (significant value $=.000$ ). It could be inferred that $\mathrm{H}_{1}$ was accepted since $0.000<0.05$. It could be concluded that there was an improvement of the students' vocabulary after the implementation of Funny Stories for the second grade students of SMA YADIKA Bandar Lampung. Therefore, the hypothesis was accepted.

Table 3. Result of the Questionnaire

\begin{tabular}{|cc|}
\hline Questions & $\begin{array}{c}\text { The Percentage in } \\
\text { Each Questions }\end{array}$ \\
\hline Q1 & $77,5 \%$ \\
\hline Q2 & $80,0 \%$ \\
\hline Q3 & $85,8 \%$ \\
\hline Q4 & $80,0 \%$ \\
\hline Q5 & $81,7 \%$ \\
\hline Q6 & $84,2 \%$ \\
\hline Q7 & $81,7 \%$ \\
\hline Q8 & $82,5 \%$ \\
\hline Q9 & $80,0 \%$ \\
\hline Q10 & $78,3 \%$ \\
\hline Q11 & $87,5 \%$ \\
\hline Q12 & $81,7 \%$ \\
\hline Q13 & $86,7 \%$ \\
\hline Q14 & $85,8 \%$ \\
\hline Q15 & $86,7 \%$ \\
\hline
\end{tabular}

Table 3 shows the result of response questionnaire. Based on the data obtained from the questionnaire, it was found that the majority of students agree to use Funny Stories to apply in vocabulary. It can be concluded that the students' responses toward the use of Funny Stories were positive. 


\section{Discussions}

\section{Significant Improvement of Students' Vocabulary After the use of Funny Stories}

Ordinarily, this section discusses about the results of the research that had been mentioned before. After calculating the data, the researcher found the answer of this research question. Explicitly, the researcher found that teaching vocabulary through funny stories was able to give a significant improvement to the students' vocabulary. The first result comes from the gain on pre-test and post-test score. Stand on the data, the students mean score of pre-tests was 77.08 and the mean score of post-tests was 86.17 , so the mean score increased 9.08 points.

In this research, there was only one class used as the sample of the research. In this research, some tests were conducted to collect the data such as pre-test and post-test. The research was started by conducting pre-test and was finished by conduction post-test. The students were given two times of treatments. After conducting the post-test, the result was analyzed by using SPSS. This study found that teaching vocabulary by using funny stories was effective.

In order to know the basic ability of the students in vocabulary, the pre-test was administered in the first meeting of the research. The highest score of pre-tests was 90 and the lowest score was 67,5. As the result, the students' score of pre-test and post-test were compared to know the significant improvement of the students. The highest score of students' post-tests was 92.5 and the lowest score was 77,5. There was an improvement of XI IPA 1 students' vocabulary since tvalue was higher than t-table. It indicated that the hypothesis propose was accepted. Moreover, it implies that funny stories had positive effects on students' vocabulary mastery. This supports the previous research finding conducted by Hernawati (2015) which focused on building up the students' English vocabulary through funny stories at Junior High School 2 Duampanu Kab. Pinrang. The researcher concludes that teaching vocabulary through funny stories can improve the students' vocabulary. In her research, she found that Funny Stories is a good for learning and teaching English vocabulary because it will train the students' brain, interest, and motivation. And then, this technique can make the students easy to understand the meaning of the words. In addition, Astusti (2005) in her research, it is stated that by using funny stories the learning process could be more enjoyable, more effective, therefore it will be easy for the students to learn new words. From the explanation above, the researcher concluded that funny stories is an effective for teaching vocabulary and funny stories could improve students' vocabulary.

Viewed from the mean score of pre-tests, the researcher found that the students' vocabulary mastery was still low. They were still lack of knowledge of content word types. It was difficult to the students to define and determine the adjective. Then, the students also had the difficulties to differentiate between verb and noun.

In terms of verb type, the students were still confused to assign which one belongs to verb type. The last type of content word which is adverb, the students were just still confused where to put adverbs properly in the sentence. Habitually, the students were still perplexed by the use of each type of content words.

Therefore, the researcher conducted the treatments and gave the students material and test which

U-JET, Vol 10, No 2, 2021 
were relevant to the students' capacities. According to Hughes (1989) who stated that a test, part of test, or a testing technique is said to give construct validity when the material and the test were used to measure the ability which it is supposed to measure. In this case the researcher conducted story as the treatment and used funny stories as the material of treatments and vocabulary test in the form of multiple-choice questions as the test to be measured. During the treatment, the students were excited to join the online class. They were excited to tell their stories and each of them wants to know each other's stories so they look interested in asking a lot of questions related to their friends' stories. The students felt excited and enjoyed in learning vocabulary by using funny stories because funny story will guide students in learning words by the curiosity in understanding the story.

To briefly paraphrase the findings of the research, the students gained much improvement after the use of funny stories in their vocabulary scores. Naturally, the improvement of students' score happened not only in eleventh grade students of senior high school but it also could be happened in junior high school students. It means that funny stories was effective to put in every ages and grades.

To wrap it all, the students of XI IPA 1 enjoyed learning process by using funny stories. Depending the research process, they could explicitly define the meaning of the words, determine the word classes, and finding the difficult words. These facts accounted why their scores improved in post-test. The improvement was not only because they were able to apply the funny stories as a learning strategy, but they also felt motivated to apply the funny stories strategy in their vocabulary learning.

In the final analysis, it was found that funny stories could improve students' vocabulary. In conclusion, it could be fairly approved that funny stories is an effective strategy for teaching vocabulary at the eleventh-grade students of SMA YADIKA Bandar Lampung.

\section{The Students' Responses after the Use of Funny Stories in Vocabulary}

The result of students' questionnaire had shown that most of the students had positive responses after the use of funny stories in teaching vocabularies. Most of them choose strongly agree and agree with the positive statements of Funny Stories in the questionnaire. On the contrary, one of the students choose disagree with negative statements of Funny Stories in the questionnaire. In other words, the students' perceived that funny stories help them in learning vocabulary.

During the treatment process, the researcher used funny stories as a learning strategy because Hernawati (2015) states that Funny Stories is a good for learning and teaching English vocabulary since it will train the students' brain, interest, and challenge. Furthermore, after the researcher used Funny stories in its class, it can be seen that the students more interested to learn new vocabulary. They gave many questions to the teacher since they did not know how to make a whole sentence. The online class runs attractively and spread enthusiasm among the class. It was a different situation comparing to the moment before researcher given the treatment. 
Based on the result of the data analysis of the questionnaire, it was found out that among 30 students, 29 students $(96,7 \%)$ had positive responses and 1 student $(3,3 \%)$ had a negative response after the u se of Funny Stories. The majority of the students $(96,7 \%)$ assume that the implementation of the Funny Stories in teaching vocabularies was very good for them.

Related to the answer of the students it showed that the funny story gave some advantages to them. First, the Funny Stories is interesting. Second, the atmosphere of learning becomes more active and enthusiastic. Third, the Funny Stories facilitates them to be brave in exploring their ability in English.

Having considered the discussion above, it was true that the students' response after the use of Funny Stories in teaching vocabularies were strongly positive. On the other hand, even one of them had a negative response; still, all the students showed significant improvement in their vocabulary achievement. It was the same with students who had a positive response, their posttest score showed significant improvement after the implementation of Funny Stories. Thus, could be justified, The Funny Stories gave many advantages to the students in the learning process. Therefore, in this research the implementation of the Funny Stories was suitable to improve students' vocabulary achievement.

\section{CONCLUSIONS AND SUGGESTIONS}

\section{Conclusions}

Based on the result and discussion, two conclusions can be stated as follows: (1) The implementation of Funny Stories could improve the students' vocabulary. Moreover, the use of Funny Stories is effective to be used in learning activities, The students were more interested and motivated in joining the class. It is proved by the statistical result in the previous chapter which shows that t-value (10.266) is higher than t-table (2.0423) and the significant value $(0.00)$ which is lower than 0.05 . (2) The students' response through the implementation of the Funny stories in teaching vocabularies is positive. It can be seen from their activity in the classroom and the data analysis. Students saw their enthusiasm in the class during the treatment process. They were so active in asking the teacher or their friends related to the story. This situation in line with the result of the data analysis, from 30 students' only one student had negative response. Even one of them had negative response; their score from pretest to posttest was significantly improved.

\section{Suggestions}

Regarding the several conclusions above, the researcher would like to proposed some suggestions. Firstly, for the teacher, since the research was conducted in an online class because of covid-19 pandemic, and the researcher found that the students are quite lazy to join the class. Therefore, the teacher should assure students' participation during the online class and there are some ways to enhance students' participation in online class. One of them is to choose engaging topic for students' discussion. Another way is to 
provide interesting media or strategy in the process of learning. Those alternatives can be used to keep students' focus and participation during the learning. The teacher can apply funny stories for writing, reading, listening and also speaking skill. Secondly, for further researcher, it is suggested other researchers apply Funny Stories in different level of school or different skill. The treatment should be applied more than two meetings in order to get more accurate results of data. Longer the frequency of the treatment day is needed to get a better finding. Since, all of the activities were done in online setting, futher researchers may try to mix the online setting with face-to-face learning in order to maximize the process and output of the teaching learning activites.

\section{REFERENCES}

Arafa, Sheila Maildha. (2018). Improving vocabulary mastery through extensive reading for grade X students of SMA N 1 SEWON. Thesis, Yogyakarta: Sanata Dharma University.

Astuti. (2015). Teaching vocabulary to the second year students' of SMAN 8 Makassar by using funny stories. Thesis, Makasar: Makasar University.

Hatch and Brown. (1995). Vocabulary, semantic and language education. Cambridge University Press. Studies in Second Language Acquisition, 19 (1), 125-126.

Hernawati. (2015). Building up the students' English vocabulary through funny stories at SMP Negeri 2 Duampanua. Journal English Language Teaching (ELT), 1(2), December 2015.

Hughes, Arthur. (1989). Testing for language teachers. Cambridge: Cambridge University Press.

Richard, J.C. and W.A. Renandya. (2002). Methodology in language teaching. New York: Cambridge University Press.

Setiyadi, B. (2006). Metode penelitian untuk pengajaran bahasa asing: Pendekatan kuantitatif dan kualitatif. Yogyakarta: Penerbit Graha Ilmu.

Thonbury, S. (2002). How to teach vocabulary. London: Longman. 